\title{
IMPACT OF P53 MODULATION ON INTERACTIONS BETWEEN P53 FAMILY MEMBERS DURING HACAT KERATINOCYTES DIFFERENTIATION
}

Rusanov $\mathrm{AL}^{1}{ }^{凶}$, Kozhin $\mathrm{PM}^{1,2}$, Romashin $\mathrm{DD}^{1}$, Karagyaur $\mathrm{MN}^{1}$, Luzgina $\mathrm{NG}^{1}$

${ }^{1}$ Institute of Biomedical Chemistry (IBMC), Moscow, Russia

${ }^{2}$ RMA "Perspektiva", Novosibirsk, Russia

HaCaT cell line is a widely used model for studying normal human keratinocytes. However, mutations of TP53 gene are typical for this cell line, which have a substantial impact on functions of the encoded protein. The features of this regulatory circuit should be considered when using HaCaT cells for assessment of human skin physiology and pathology in vitro. The study was aimed to assess the features of differentiation realization in HaCaT cells with modulated activity of p53 protein. The expression of p53 was reduced by knockdown of TP53 gene by shRNA (by 2.2 times, $p<0.05$ ), and the elevated concentration of the p53 active forms was achieved via exposure of cells to Nutlin-3a, the MDM2 inhibitor and the major negative regulator of p53. It has been found that regulation of at least three differentiation markers, CASP14, IV (expression increase by 3.9 and 3.7 times respectively in the p53-knockdown cells, $p<0.05$ ) and TGM1 (twofold expression decrease in the p53-knockdown cells, and 1.7-fold expression increase under exposure to Nutlin-3a, $p<0.05$ ) in HaCaT cells is p53-mediated. The positive correlation has been revealed for expression of TGM1 and p53 that might be realized indirectly via $\triangle \mathrm{Np} 63$ expression alteration. At the same time, modulation of p53 does not result in significant alterations in expression of cytokeratins.

Keywords: HaCaT, keratinocytes differentiation, p53, p63, $\triangle$ Np63, TAp63, Nutlin-3a, shRNA, knockdown

Funding: the study involving p53 gene knockdown, ELISA and PCR tests was performed as part of the Fundamental Scientific Research Programs of the State Academies of Sciences for 2013-2020; experiments with Nutlin-3a were carried out by RMA "Perspektiva” and supported by RFBR, project № 18-44-540031/19.

Author contribution: Luzgina NG, Rusanov AL — study concept; Romashin DD, Kozhin PM, Luzgina NG, Rusanov AL — study design and literature analysis: Romashin DD, Kozhin PM, Karagyaur MN — study planning and execution; Kozhin PM, Romashin DD, Luzgina NG, Rusanov AL — data analysis and interpretation; Kozhin PM, Romashin DD - manuscript writing; Kozhin PM, Romashin DD, Karagyaur MN, Luzgina NG, Rusanov AL - manuscript editing, preparation of the final version of the article.

Compliance with ethical standards: the study was carried out in accordance with the World Medical Association Declaration of Helsinki.

$\triangle$ Correspondence should be addressed: Alexander L. Rusanov

Pogodinskaya, 10, str. 8, Moscow, 119121; alexander.l.rusanov@gmail.com

Received: 27.11.2020 Accepted: 14.12.2020 Published online: 25.12.2020

DOI: $10.24075 /$ brsmu.2020.082

\section{ВЛИЯНИЕ МОДУЛЯЦИИ АКТИВНОСТИ Р5З НА ВЗАИМОДЕЙСТВИЕ ЧЛЕНОВ СЕМЕЙСТВА Р5З В ПРОЦЕССЕ ДИФФЕРЕНЦИРОВКИ КЕРАТИНОЦИТОВ ЛИНИИ НАСАТ}

\author{
А. Л. Русанов ${ }^{1 凶}$, П. М. Кожин ${ }^{1,2}$, Д. Д. Ромашин ${ }^{1}$, М. Н. Карагяур ${ }^{1}$, Н. Г. Лузгина ${ }^{1}$ \\ ${ }^{1}$ Научно-исследовательский институт биомедицинской химии имени В. Н. Ореховича (ИБМХ), Москва, Россия \\ 2 ООО НПО «Перспектива», Новосибирск, Россия
}

Клетки линии НаСаТ являются распространенной моделью для исследования нормальных кератиноцитов человека. Однако для клеток этой линии характерны мутации в гене ТР53, что существенно сказывается на функциях кодируемого белка. Особенности данного регуляторного контура необходимо учитывать при использовании клеток НаСаТ в качестве объекта исследований физиологии и патологии кожи человека іn vitro. Целью исследования было изучить особенности реализации программы дифференцировки в клетках линии НаСаТ в условиях модуляции активности белка p53. Снижения уровня экспрессии р53 добивались нокдауном гена TP53 с помощью shRNA (в 2,2 раза, p < 0,05), и, напротив, увеличения концентрации активных форм данного белка в клетках достигали за счет воздействия на клетки Nutlin-3а - ингибитора MDM2, основного негативного регулятора р53. Установлено, что регуляция как минимум трех маркеров дифференцировки, CASP14, IVL (увеличение экспрессии в 3,9 и 3,7 раза соответственно при нокдауне p53, p < 0,05) и TGM1 (уменьшение экспрессии вдвое при нокдауне TP53 и увеличение в 1,7 раза при воздействии на клетки Nutlin-3а, p < 0,05), в клетках НаСаТ зависит от активности р53. При этом в отношении экспрессии ТGМ1 и р53 отмечена прямая зависимость, которая, возможно, реализуется опосредованно, через изменение экспрессии $\Delta$ Np63. В то же время модуляция активности р53 не приводит к значительным изменениям экспрессии цитокератинов.

Ключевые слова: НаСаT, дифференцировка кератиноцитов, p53, p63, $\Delta$ Np63, TAp63, Nutlin-3a, shRNA, нокдаун

Финансирование: работа, включающая нокдаун гена р53, ИФА и ПЦР-исследования, выполнена в рамках Программы фундаментальных научных исследований государственных академий наук на 2013-2020 годы; эксперименты с применением Nutlin-3a были проведены на базе ООО НПО «Перспектива» при поддержке РФФИ, научно-исследовательский проект 18-44-540031/19.

Вклад авторов: Н. Г. Лузгина, А. Л. Русанов - концепция исследования; Д. Д. Ромашин, П. М. Кожин, Н. Г. Лузгина, А. Л. Русанов - дизайн исследования и анализ литературы; Д. Д. Ромашин, П. М. Кожин, М. Н. Карагяур - планирование и проведение исследования; П. М. Кожин, Д. Д. Ромашин, Н. Г. Лузгина, А. Л. Русанов - анализ и интерпретация данных; П. М. Кожин, Д. Д. Ромашин - подготовка текста статьи; П. М. Кожин, Д. Д. Ромашин, М. Н. Карагяур, Н. Г. Лузгина, А. Л. Русанов - редактирование рукописи, подготовка финального варианта статьи.

Соблюдение этических стандартов: исследование проведено в соответствии с требованиями Хельсинкской декларации Всемирной медицинской ассоциации.

$\triangle$ Для корреспонденции: Александр Леонидович Русанов

ул. Погодинская, д. 10, стр. 8, г. Москва, 119121; alexander.l.rusanov@gmail.com

Статья получена: 27.11.2020 Статья принята к печати: 14.12.2020 Опубликована онлайн: 25.12.2020

DOI: $10.24075 /$ vrgmu.2020.082 
Terminal differentiation of keratinocytes is one of the possible programmed cell death pathways. This process ensures normal stratification of epidermal cells required for the normal epidermal barrier formation. Various impairments of terminal differentiation underlie clinical manifestations of many chronic skin disorders. Recently, the role of p53 proteins in regulation of keratinocyte differentiation has been actively studied [1-4].

It is known that p53 protein accumulates and induces apoptosis in epidermal cells in response to sunburn [5] and a number of other cytotoxic effects. Furthermore, active forms of the proteins are most often detected in proliferating keratinocytes, but not in differentiated cells [6]. In one view, p53 may play a dual role in survival of epidermal cells supporting "healthy" proliferative cells and inducing apoptosis in severely damaged cells [7].

According to some authors, p53 promotes proliferation and slows down differentiation of normal human keratinocytes by inactivation of signaling pathway mediated by MYC protooncogene [7]. Yet in p53-knockdown cells the significantly increased expression of such cell differentiation markers as involucrin, keratins KRT1 and KRT10, and filaggrin was observed. Generally, cells with inactivated p53 were characterized by higher rate of stratification and detachment [7]

However, the specific role of p53 family proteins and their interactions at different stages of the human keratinocytes' differentiation in healthy and diseased organism is poorly understood.

The role of p53 family proteins in regulation of proliferation and differentiation of HaCaT line keratinocytes, the spontaneously immortalized non-carcinogenic human keratinocyte cell line, is even less studied [8]. This cell line is widely used as a mode for studying the normal human keratinocyte functions $[9,10]$. However, HaCaT keratinocytes are characterized by abnormal stratification and aberrant differentiation marker expression [11]

It is known that genome of HaCaT keratinocytes contains two alleles of TP53 gene (H179Y and R282Q) with two gain-offunction (GOV) mutations acquired as a result of spontaneous immortalization (mutp53) [12]. In HaCaT cell line, mutp53 promotes proliferation and cell growth; it contains over 7,000 sites for DNA biding. The protein functions related to apoptosis induction are preserved [4].

Moreover, unlike normal keratinocytes, HaCaT cells predominantly express $\Delta N p 63 \alpha$ isoform of p63, and TA isoform is almost undetectable [13].

Understanding HaCaT cells' physiology and underlying functions is necessary to assess the limitations when using such cells as a model. Furthermore, studying the p53 family proteins' interactions in the presence of mutp53 in cell genome will provide new data relevant for the study of carcinogenesis $[14,15]$.

The study was aimed to assess the role of p53 family proteins in regulation of proliferation and differentiation of the HaCaT cells. Modulation of p53 protein was provided during the study: activation was achieved via exposure to Nutlin-3a (inhibitor of MDM2, the major negative regulator of p53), and expression of p53 was suppressed by anti-TP53 shRNA.

\section{METHODS}

\section{Cell lines and culture conditions}

HaCaT cell line was obtained from the cell culture collection of German Cancer Research Center (DKFZ, Heidelberg; Germany). The cells were cultured at 37 oC with $5 \% \mathrm{CO}_{2}$ in DMEM/F12 culture medium (1:1, Gibco; USA) containing
1\% GlutaMAX supplement (Thermo Fisher Scientific; USA), penicillin/streptomycin solution at a concentration of $100 \mathrm{U} /$ $\mathrm{ml}$ and $100 \mu \mathrm{g} / \mathrm{mL}$ respectively (Gibco; USA), as well as 10\% fetal bovine serum (Dia-M; Russia), i.e. in the complete culture medium. The cells were grown in culture flasks with a surface area of $25 \mathrm{~cm}^{2}$ or in Petri dishes with a diameter of $60 \mathrm{~mm}$ (Corning; USA). The medium was replaced with the fresh one every 48 hours of cell growth.

\section{TP53 gene knockdown using shRNA}

TP53 gene was knocked down with lentiviral vector, which encoded anti-TP53 shRNA. In order to construct the lentiviral vector, the HEK2937T cell line was transfected withpLKOp53-shRNA vector (Addgene, \#25637) in accordance with the standard polyethyleneimine (PEI) transfection protocol [16]. Conditioned medium containing the lentiviral particles was prepared 48-72 hours of incubation after transfection. In order to enhance the transduction efficiency, protamine sulfate (50 $\mathrm{\mu g} / \mathrm{mL}$ ) was added to the culture medium containing the lentiviral particles. For transduction, $\mathrm{HaCaT}$ keratinocytes were grown to 40-50\% confluence, and the culture medium was replaced by the lentiviral particles containing medium. Then the cells were centrifuged at $800 \mathrm{~g}$ for 1.5 hours. After centrifugation the conditioned medium was replaced by the complete culture medium. The wild-type control (WT HaCaT) transduced with the lego-ig2 vector (Addgene \#27341) containing no puromycin resistance gene was used for selection with puromycin. The transduced cells of both cell lines (control and treated) were cultured at $37{ }^{\circ} \mathrm{C}$ with $5 \% \mathrm{CO}_{2}$ for 4 days. After that culture medium was replaced by puromycin containing medium $(1 \mu \mathrm{g} / \mathrm{mL})$, and the cells were cultured up to $100 \%$ control cells death. During this period the non-transduced cells of the treated cell line also died.

\section{Assessment of gene expression level}

The cells were grown in the $60 \mathrm{~mm}$ Petri dishes with the complete culture medium at $37{ }^{\circ} \mathrm{C}$ with $5 \% \mathrm{CO}_{2}$. Upon reaching $60 \%$ confluence, the culture medium was replaced by the Nutlin-3a-containing medium (Merck; Germany). The cells were incubated for 24 hours and used for further experiments.

RNA was isolated using the RNeasy Kit (QIAGEN; USA) in accordance with the manufacturer's protocol. The isolated RNA was quantified using the NanoDrop 2000c system (Thermo Scientific; USA). Reverse transcription reaction was performed using MMLV RT kit (Evrogen; Russia) in accordance with the standard protocol by adding $1 \mu \mathrm{g}$ of RNA at a time. R eal-time PCR (qPCR) was carried out using the qPCRmix-HS SYBR+LowROX reaction mixture (Evrogen; Russia). For each group three biological samples were used, and reactions were carried out in three iterations for each gene and each sample. GAPDH was used as a reference gene. The primers are listed in Table 1.

\section{Metabolic activity assessment}

Cells' metabolic activity was defined using the MTT assay [17]. The cells were plated in the 96-well plate (Corning; USA) at $3.0 \times 10^{3}$ cells per well 48 hours before exposure, 6 wells for each concentration of Nutlin-3a. After two days of growth the culture medium was replaced by the fresh one containing Nutlin-3a at a concentration of $0.2-50 \mu \mathrm{M}$, then the cells were incubated for 24 hours. After cultivation the medium was replaced by the fresh one containing MTT (Dia-M; Russia) at 
Table 1. Primers

\begin{tabular}{|c|c|}
\hline Gene & Primer nucleotide sequence \\
\hline$G A P D H$ & $\begin{array}{l}\text { Forward 5'-TCGACAGTCAGCCGCATCTTCTTT-3' } \\
\text { Probe R6G-5'-AGCCGAGCCACATCGCTCAGACACCAT-3'-Q } \\
\text { Reverse 5'-ACCAAATCCGTTGACTCCGACCTT-3' }\end{array}$ \\
\hline TP53 & $\begin{array}{l}\text { Forward 5`-CTCACCATCATCACACTGGAA-3`' } \\
\text { Probe FAM-5'-TACTGGGACGGAACAGCTTTGAGG-3'-Q } \\
\text { Reverse 5'-CCAGGACAGGCACAAACA-3`' }\end{array}$ \\
\hline$\Delta N p 63$ & $\begin{array}{l}\text { Forward 5'-AGAAGAAAGGACAGCAGCATTGAT-3' } \\
\text { Probe FAM-5'-TCCTGAACAGCATGGACCAGCAGA-3’-Q } \\
\text { Reverse 5'-GGACGAGGAGCCGTTCTGA-3` }\end{array}$ \\
\hline TAp63 & $\begin{array}{l}\text { Forward 5'-CCAGAGCACACAGACAAATG-3' } \\
\text { Probe FAM-5'-ACAGCCTATATGTTCAGTTCAGCCCA-3'-Q } \\
\text { Reverse 5'-TGATGGTTCATCCACAAAGTTC-3`' }\end{array}$ \\
\hline TP63 & $\begin{array}{l}\text { Forward 5'-CGTACAGGCAACAGCAACAG-3` } \\
\text { Probe FAM-5`-CAGCAGCACCAGCACTTACTTCAGA-3`-Q } \\
\text { Reverse 5'-CACAGAAGGCAGCTTGTTCA-3`' }\end{array}$ \\
\hline TGM1 & $\begin{array}{l}\text { Forward 5'-TGCTGGATGCCTGCTTAT-3' } \\
\text { Probe FAM-5'-TGGTGAACTCCCTGGATGACAATGG-3'-Q } \\
\text { Reverse 5'-ACCAGACCAGTTCCCAATC-3` }\end{array}$ \\
\hline$I V L$ & $\begin{array}{l}\text { Forward 5'-CCAAAGCCTCTGCCTCAG-3` } \\
\text { Probe FAM-5'-AGATGTCCCAGCAACACACACTGC-3'-Q } \\
\text { Reverse 5'-GTATTGACTGGAGGAGGAACAG-3' }\end{array}$ \\
\hline KRT14 & $\begin{array}{l}\text { Forward 5`-CTGAAGAAGAACCACGAGGA-3`' } \\
\text { Probe FAM-5'-AGGTGGGTGGAGATGTCAATGTGG-3'-Q } \\
\text { Reverse 5'-TCTCTGCCATCTTCTCATACTG-3`' }\end{array}$ \\
\hline KRT10 & $\begin{array}{l}\text { Forward 5`-AGCATGGCAACTCACATCA-3`' } \\
\text { Probe FAM-5'-ATTTGCTGTAGTCACGAGGCTCCC-3'-Q } \\
\text { Reverse 5`-GTCGATCTGAAGCAGGATGTT-3`' }\end{array}$ \\
\hline CASP14 & $\begin{array}{l}\text { Forward 5'-CCTGTCGAGGAGAACAAAGG-3`' } \\
\text { Probe FAM-5'-AAAGACAGCCCACAAACCATCCCA-3'-Q } \\
\text { Reverse 5'-TGCAAGGCATCTGTGTATGT-3`' }\end{array}$ \\
\hline
\end{tabular}

a concentration of $1 \mathrm{mg} / \mathrm{mL}$. The cells were incubated for 2 hours, and formazan formed granules were dissolved in DMSO (Helicon; Russia). Then the optical density was measured at a wavelength of $490 \mathrm{~nm}$. The experiment was carried out in three biological replicates.

\section{Enzyme-linked immunosorbent assay (ELISA)}

Semiquantitative analysis of p53 was performed using the ab205713 kit (Abcam; UK) in accordance with the manufacturer's instructions. The cells were plated in the 96well plate in three replicates at $1 \times 10^{4}$ cells per well. The signal intensity was measured using the iMark spectrophotometer (Bio-Rad; USA) at a wavelength of $450 \mathrm{~nm}$.

\section{Immunofluorescence staining}

For immunofluorescence studies, the cells were cultured on coverslips in 6 -well plates. The cells were fixed in $4 \%$ formalin, permeabilized by $0.1 \%$ Triton $X-100$, and stained with primary antibodies to $\triangle N p 63$ (\#619002, Biolegend; USA), TAp63 (\#618902, Biolegend; USA), KRT5 (ab52635, Abcam; UK), KRT10 (ab9025, Abcam; UK) and secondary Alexa Fluor 488-conjugated (ab150105, Abcam; UK) or Texas Redconjugated (ab6793, Abcam; UK) antibodies. All preparations were stained simultaneously using the same reagent kit (dilutions of antibodies and buffers). The experiment was carried out in three biological replicates.

The preparations were sequentially visualized with the LSM 710 confocal laser scanning microscope (Carl Zeiss; Germany) using the same settings. At least 5 fields of view were photographed for each preparation. The images were processed with CellProfiler 3.1.9 software [18]. At least 100 cells were analyzed for each sample, and mean fluorescence intensity (cell fluorescence intensity divided by cell area) was calculated. The mean fluorescence intensity values were normalized to mean fluorescence intensity of the control.

\section{Data analysis}

The data of three biological replicates were used for analysis. The results were processed using the $\mathrm{R}$ programming language [19]. The differences in the values of the studied parameters between groups were determined using the Student's $t$-test with Benjamini-Hochberg adjustment for multiple comparisons. The differences were considered significant when $p<0.05$. The data are presented as $\mathrm{M} \pm m$.

\section{RESULTS}

The knockdown of TP53 in the HaCaT cell line was confirmed by enzyme-linked immunosorbent assay (ELIZA). The antiTP53 shRNA transduction resulted in significantly decreased (by 2.2 times, $p<0.05$ ) intracellular p53 concentration, by not to complete lack of intracellular p53 (ELIZA) (Fig. 1A).

Metabolic activity of wild-type cells and TP53-knockdown cells when exposed to inhibitor of MDM2, Nutlin-3a, was assessed using the MTT assay (Fig. 1B). The 24-hour exposure to Nutlin-3a resulted in the dose-dependent decrease in amount of formazan produced by wild-type HaCaT cells. The IC10 and IC50 values were $0.18 \pm 0.10 \mu \mathrm{M}$ and $129.11 \pm 167.78 \mu \mathrm{M}$ respectively.

Similar treatment of TP53-knockdown cells did not affect the production of formazan. Significant differences in the amount of formazan produced by these cells compared to wild-type cells were observed when exposed to Nutlin-3a concentrations of 
$10 \mu \mathrm{M}$ and more. Therefore, Nutlin-3a concentration of $10 \mu \mathrm{M}$ was used in subsequent experiments.

The identified features of the Nutlin-3a effect of TP53knockdown cells may be associated with significantly reduced level of active p53 forms in these cells. Nevertheless, blocking MDM2-mediated degradation of p53 by Nutlin-3a does not appear to result in an increase in its concentration sufficient for realization of p53 major effects (cell cycle arrest, apoptosis).

Expression levels of a number of proteins' genes which reflected the activity of keratinocyte differentiation processes in intact wild-type cells and TP53-knockdown cells were different (Fig. 2A). Thus, higher expression of genes encoding involucrin and caspase-14, and lower expression of TGM1 gene was observed in the knockdown cells compared to wild-type cells. No significant differences in the levels of cytokeratin expression (PCR, fluorescence microscopy) were detected (Fig. 2 A, B, C). Furthermore, the knockdown cells demonstrated decreased expression of genes encoding p63, $\triangle N p 63$ and TAp63 isoforms. Reduced level of the listed proteins in cytoplasm and nucleus was also detected (microscopy) (Fig. 3 A, B).

Exposure of wild-type cells to Nutlin-3a resulted in twofold increase of $P 21$ gene activity, which indicated the accumulation of p53 active forms in the cells. We also detected the increased expression of TGM1 gene responsible for synthesis of p63 isoform ( $\triangle N p 63)$, and the slightly increased expression of $I V L$. However, the level of the latter remained significantly lower compared to knockdown cells. At the same time, no significant alterations in the levels of CASP14 and cytokeratins 14 and 10 expression were detected (PCR). Cytokeratin 10 expression level was confirmed by microscopy. We also detected an increase in the level of cytokeratin 5 by 1.54 times (microscopy). It should be noted that along with the elevated expression of $\triangle N p 63$, a decrease in the level of this protein was observed both in nucleus and in cytoplasm of the cells. The level of TAp63 in nucleus and cytoplasm increased.

\section{DISCUSSION}

The study was aimed to investigate the effect of p53 family proteins on HaCaT keratinocyte differentiation. We assessed the differentiation markers' expression alterations in relation to activity of p53: the reduced expression of p53 was obtained by

A

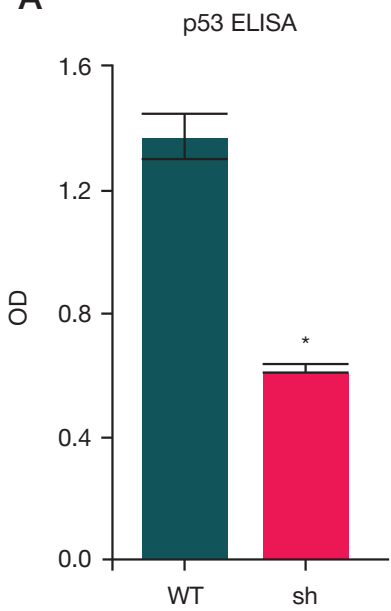

B

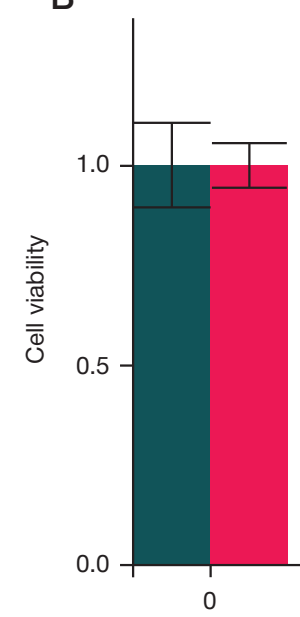

knockdown of TP53, and activity of the protein was increased by Nutlin-3a added to the culture medium.

Proteins, the expression of which in normal keratinocytes increases as epidermal cells move from stratum basale to stratum corneum, have been selected as keratinocytes' differentiation markers (IVL, TGM1 and CASP14). Thus, involucrin (IVL) is the structural protein of keratinocytes responsible for mechanical strength of the epidermal barrier. Furthermore, complexes of involucrin with lipids (omega-hydroxyceramides) are involved in the corneocyte lipid envelope formation [20]. Involucrin is one of the major substrates of transglutaminase 1 (TGM1), which catalyzes the formation of cross-links between lysine residues in structural proteins of epidermis [21]. TGM1 is critical for epidermal barrier formation [21]. Unlike other proteins of the discussed family, caspase-14 (CASP14) is specifically expressed in epidermis, which plays particularly no role in realization of apoptosis, and is responsible for regulation of keratinocyte differentiation [22].

To assess the degree of cell differentiation, we studied the expression of keratins, KRT10, KRT5, KRT14 (components of the keratinocyte cytoskeletal intermediate filament proteins). It is known that high levels of KRT1 and KRT10 are most typical for differentiating keratinocytes [23], in contrast to keratins KRT5 and KRT14 actively expressed in cells of stratum basale [24].

The expression of other p53 family members, $\triangle N p 63$ and TAp63, was assessed using the same experimental conditions, which made it possible to evaluate its relationship to p53 activity.

Earlier the effect of reduced p53 expression (resulting from the TP53 knockdown) on the normal human keratinocytes differentiation markers' expression had been studied [7]. Thus, the comparison of experimental results with literature data may enable us to obtain information about similarities and differences in the effects of p53 proteins on cell differentiation in the normal keratinocytes and HaCaT cell line.

It should be noted that during our study we failed to achieve the complete suppression of the p53 expression in the HaCaT cells. This could be due to the cell line resistance to reagents for transduction/transfection (compared to epithelial cells of internal organs) [25]. However, the p53 expression reduction was significant (2.2-fold).

Among the studied markers of keratinocyte differentiation, IVL, CASP14 and TGM1 genes were to a greater extent

Fig. 1. Effects of TP53 modulation by knockdown and exposure to Nutlin-3a. A. Semiquantitative analysis of p53 in wild-type cells (WT) and TP53-knockdown cells (sh). B. Metabolic activity of cells (MTT assay) after exposure to Nutlin-3a. * - significant differences between groups WT and sh ( $p<0.05)$ 
associated with alterations in expression of p53. The expression of TGM1 gene was the most p53-dependent: the expression level significantly decreased in TP53-knockdown cells and increased under exposure to Nutlin-3a.

It should be noted that the expression levels of TGM1 and involucrin, the protein being a substrate for TGM1, as well as the dynamics of these parameters' values in the studied experimental situations did not match up. The expression of involucrin significantly increased in the TP53-knockdown cells. However, it also slightly increased under exposure to Nutlin-3a. Despite the obvious functional relationship between TGM1 and involucrin, the expression of those in $\mathrm{HaCaT}$ cells is regulated by different mechanisms.

Unlike normal keratinocytes, unresponsive to alterations in p63 expression in response to p53 knockdown [7], in our study the modulation of p53 activity in $\mathrm{HaCaT}$ cells resulted in altered expression of p63 isoforms. The decreased expression of TP63 in HaCaT cells with p53 knockdown had been reported before [4].

It is known that p63 isoforms, especially $\Delta N p 63$, inhibit activity of p53 [1]. It cannot be excluded that a high baseline expression of $\triangle \mathrm{Np63}$ in $\mathrm{HaCaT}$ cells is required for inactivation of mutp53 effects. In this context the detected alteration of p53 and p63 isoforms ( $\triangle \mathrm{Np63}$, TAp63) ratio in TP53-knockdown cells compared to intact cells seems to be natural: in the absence of protein to be inhibited (p53) the reduced expression of p63 isoforms is observed. The detected discrepancy in dynamics of $\triangle \mathrm{Np63}$ expression when exposed to Nutlin3a (elevated expression, according to PCR data, along with
A
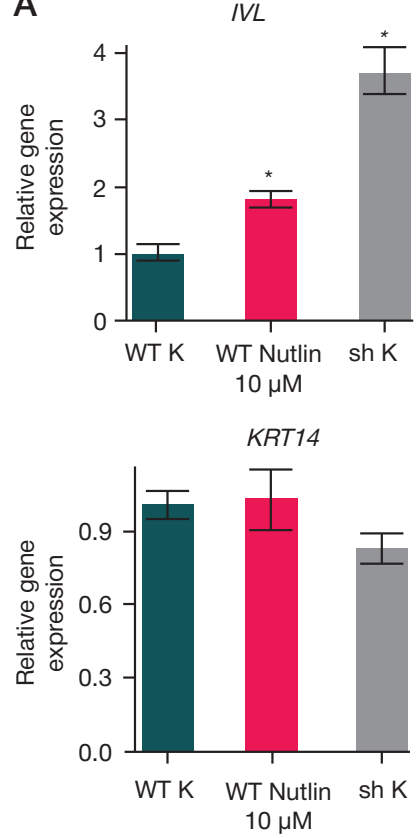

KRT10

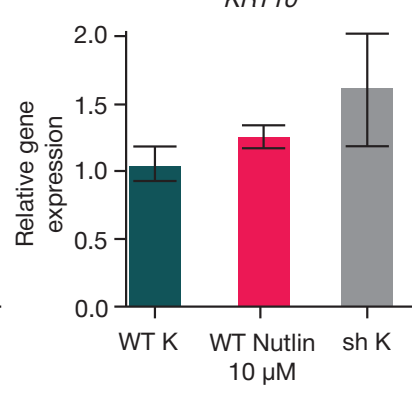

B
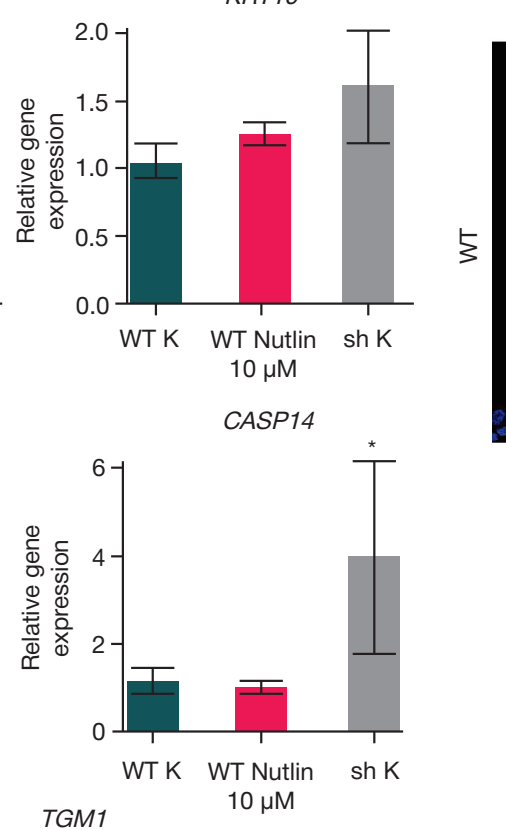

reduced level of protein in the cytoplasm and nucleus) may result from $\triangle N p 63$ protein involvement in p53 inactivation, for example, due to formation of $\Delta N p 63 / p 53$ heterodimers [26].

At the same time, the increase in TAp63 protein amount in the cells with no significant alterations in the expression of the appropriate gene in the same experimental situation may be associated with the MDM2 inhibition. According to literary sources [27] and our results, MDM2 may be a negative regulator of both p53 and TAp63.

It is known that the activity of p53 increases as keratinocytes move from stratum basale to higher layers, partly because of gradual decrease in $\triangle N p 63$ inhibitory effect. As a result, p53 implements its functions required to complete keratinization. In particular, it induces expression of TGM1, the substrate of which (involucrin) is produced in lower epidermal layers and is regulated by other mechanisms.

It cannot be excluded that the major regulator of TGM1 expression in HaCaT cells is $\triangle N p 63$ protein, but not p53 itself. As can be seen, the dynamics of the discussed protein gene expression is ipsidirectional to the expression of gene, which encodes TGM1. Such $\triangle N p 63$ expression alteration is evidently due to altered intracellular p53 activity.

In HaCaT cells, the impact of p53 activity on the expression of the other keratinocyte differentiation marker, caspase-14, is obvious. In the cells with knockdown TP53 the expression of gene encoding CASP14 is significantly increased. Presumably, in HaCaT cells p53 directly or indirectly inhibits the expression of this protein. However, the activity of such an impact is rather high: the
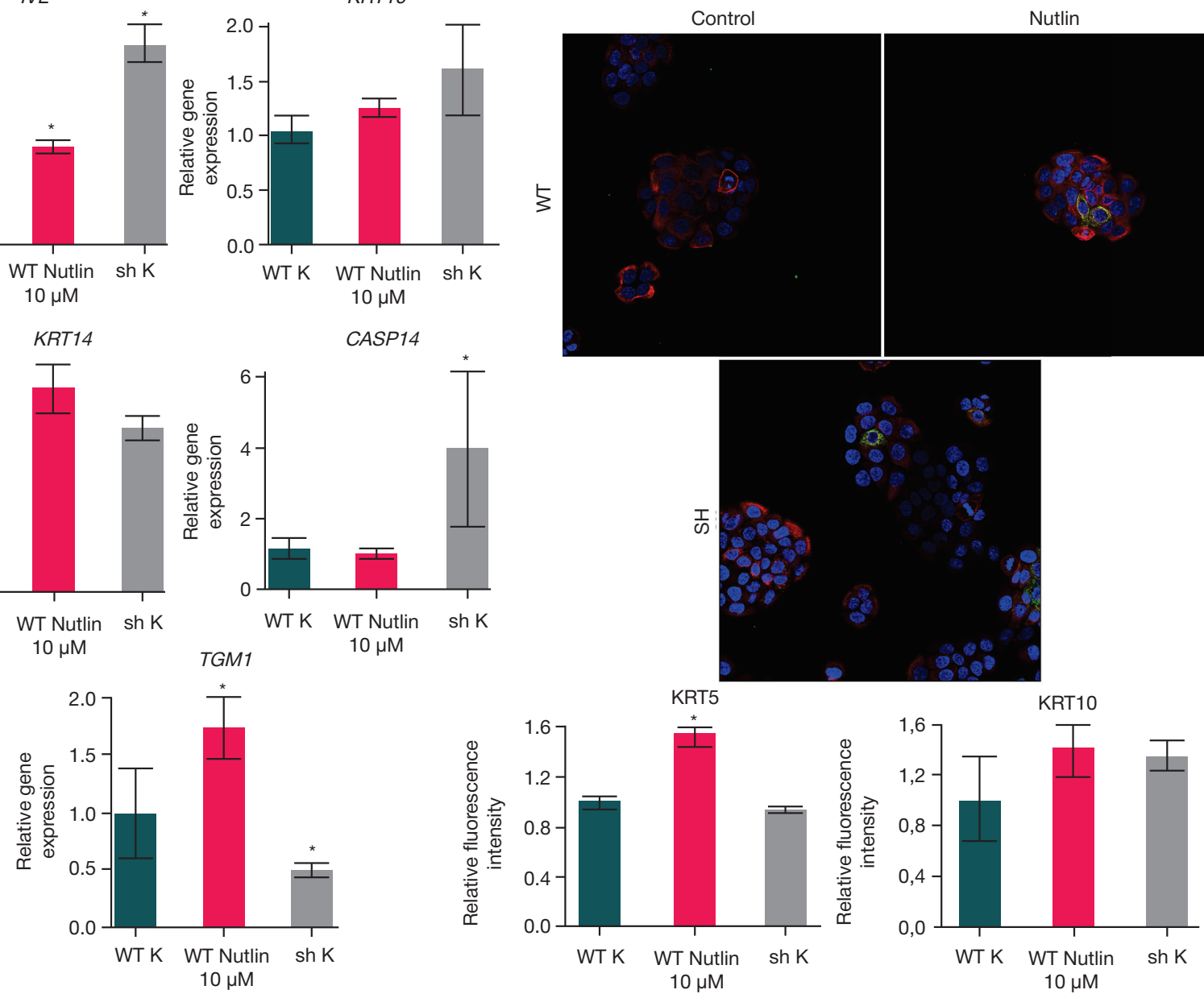

Fig. 2. Expression of differentiation markers in HaCaT cells. A. Expression of IVL, KRT10, KRT14, CASP14, TGM1. B. Immunofluorescence microscopy: KRT5 (red), KRT10 (green), DAPI (blue, nuclei), x400 magnification. C. Generalized diagram of the cells' relative fluorescence intensities. * significant differences between treated cells (sh, Nutlin-3a) and intact cells (WT K), $p<0.05$ 
A
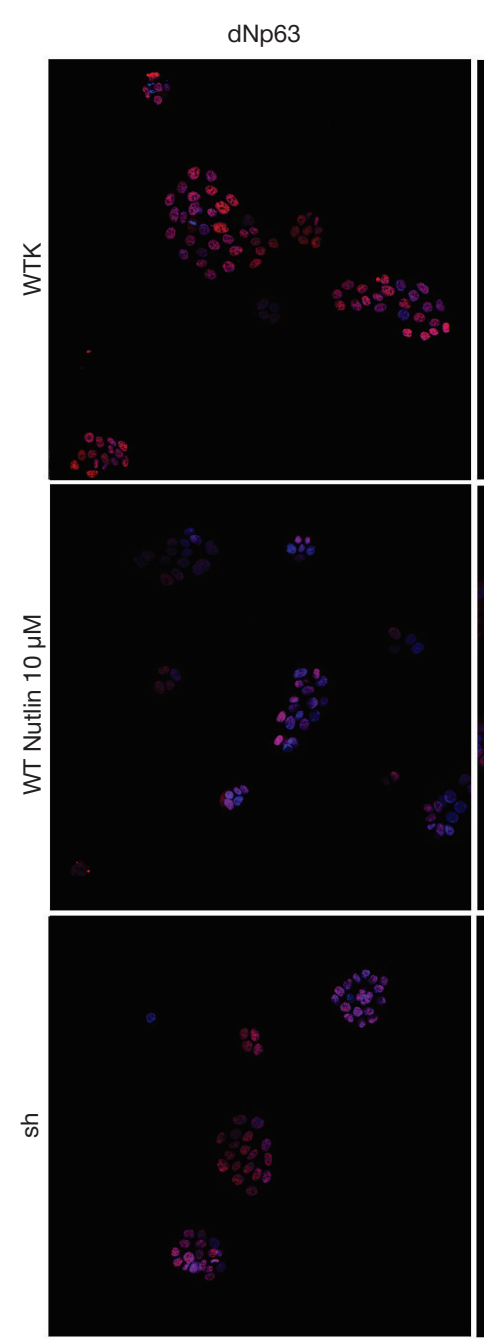

B
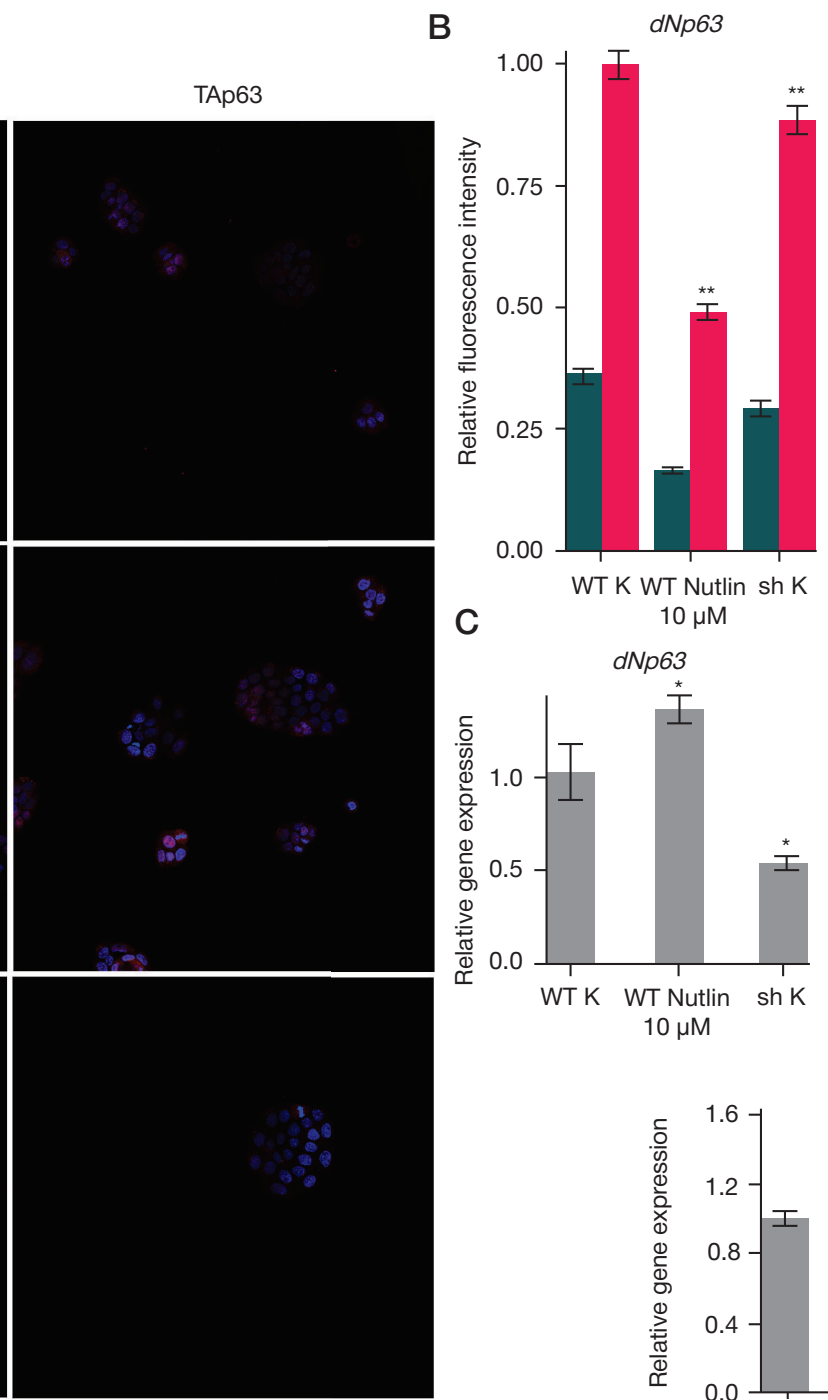
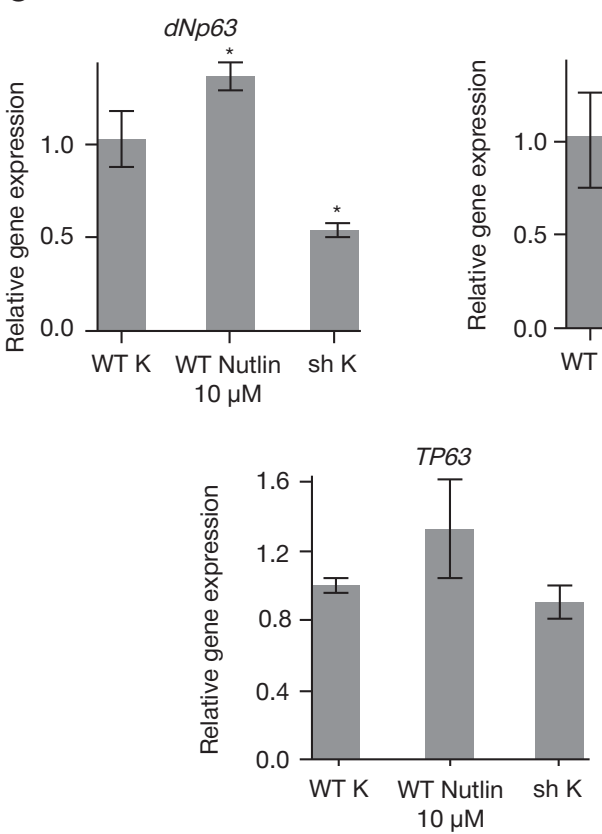

TAp63

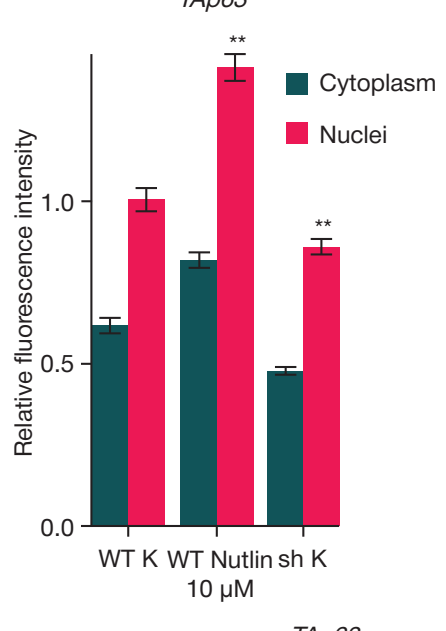

TAp63

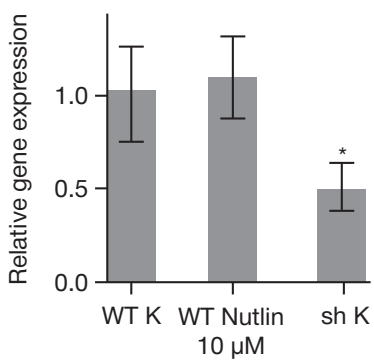

$10 \mu \mathrm{M}$

Fig. 3. Alterations in p63 isoforms' expression. A. Immunofluorescence microscopy: dNp63, TAp63 (red), DAPI (b/ue), x400 magnification. B. Generalized diagram of relative fluorescence intensities of cytoplasm and nucleus. C. Expression of TP63 isoforms (dNp63, TAp63). * — significant differences between treated cells (sh, Nutlin-3a) and intact cells (WT K), $p<0.05$

increased activity of p53 resulting from exposure of cells to Nutlin3 a does not lead to significant decrease in expression of CASP14.

It should be noted that with modulation of p53 activity in $\mathrm{HaCaT}$ cells no significant alterations in expression of cytokeratins were observed. An exception was KRT5, the marker of the lower epidermal layer cells. The expression of KRT5 slightly increased under exposure to Nutlin-3a, perhaps, due to activation of mutp53 effects contributing to cell proliferation [4]. Expression of KRT10 typical for differentiating keratinocytes [23] in the cells with p53 knockdown did not change. Yet the suppressed function of p53 in normal keratinocytes is associated with elevated expression of the discussed cytokeratins [7]. In HaCaT cells, mutp53 inhibits the expression of these proteins, even under conditions of incomplete knockdown of TP53.

\section{CONCLUSION}

Under conditions of p53 activity modulation in HaCaT cells, the expression of certain cell differentiation markers is altered, particularly, the expression of caspase-14, involucrin and transglutaminase 1, but not the expression of KRT10. Unlike normal human keratinocytes, HaCaT cells respond to reduced activity of p53 by reduced expression of p63 isoforms. The study results may be taken into account when studying the processes associated with keratinocyte differentiation, as well as when using HaCaT cell line as a cell culture model of skin. The data obtained may be used for in-depth assessment of the role of p53 family proteins expressed by HaCaT cell line in various physiological processes. 
1. Westfall MD, Mays DJ, Sniezek JC, Pietenpol JA. The $\triangle N p 63 \alpha$ phosphoprotein binds the P21 and 14-3-3 $\sigma$ promoters in vivo and has transcriptional repressor activity that is reduced by Hay-Wells syndrome-derived mutations. Mol Cell Biol. 2003; 23 (7): 2264-76.

2. Botchkarev VA, Flores ER. P53/P63/P73 in the epidermis in health and disease. Cold Spring Harb Perspect Med. 2014; 4 (8): a015248.

3. Koster MI, Roop DR. Mechanisms regulating epithelial stratification. Annu Rev Cell Dev Biol. 2007; 23 (1): 93-113.

4. Martynova E, Pozzi S, Basile V, Dolfini D, Zambelli F, Imbriano C, et al. Gain-of-function p53 mutants have widespread genomic locations partially overlapping with p63. Oncotarget. 2012 Feb; 3 (2): 132-43.

5. Ziegler A, Jonason AS, Leffell DJ, Simon JA, Sharma HW, Kimmelman J, et al. Sunburn and P53 in the onset of skin cancer. Nature. 1994; 372 (6508): 773-6.

6. Dazard JE, Piette J, Basset-Seguin N, Blanchard JM, Gandarillas A. Switch from P53 to MDM2 as differentiating human keratinocytes lose their proliferative potential and increase in cellular size. Oncogene. 2000; 19 (33): 3693-705.

7. Freije A, Molinuevo R, Ceballos L, Cagigas M, Alonso-Lecue P, Rodriguez R, et al. Inactivation of P53 in human keratinocytes leads to squamous differentiation and shedding via replication stress and mitotic slippage. Cell Rep. 2014; 9 (4): 1349-60.

8. Seo E-Y, Piao Y-J, Kim J-S, Suhr K-B, Park J-K, Lee J-H. Identification of calcium-induced genes in $\mathrm{HaCaT}$ keratinocytes by polymerase chain reaction-based subtractive hybridization. Arch Dermatol Res. 2002; 294 (9): 411-18.

9. Petushkova NA, Rusanov AL, Pyatnitskiy MA, Larina OV, et al. Proteomic characterization of HaCaT keratinocytes provides new insights into changes associated with SDS exposure. Biomed Dermatol. 2020; 4 (1): 4.

10. Rusanov AL, Nakhod KV, Nakhod VI, Poverennaya EV, Petushkova NA, Luzgina NG. Changes in the proteome of HaCaT keratinocytes induced by cytotoxic substance Triton X-100. Bull Exp Biol Med. 2017; 163 (5): 620-2.

11. Smits J, Niehues $H$, Rikken $G$, van Vlijmen-Willems I, van de Zande G, Zeeuwen P, et al. Immortalized N/TERT keratinocytes as an alternative cell source in 3D human epidermal models. Sci Rep. 2017; 7 (1): pii: 11838.

12. Lehman TA, Modali R, Boukamp P, Stanek J, Bennett WP, Welsh JA, et al. p53 mutations in human immortalized epithelial cell lines. Carcinogenesis. 1993; 14: 833-9.

13. Jung Y-S, Qian Y, Yan W, Chen X. Pirh2 E3 ubiquitin ligase modulates keratinocyte differentiation through P63. J Invest Dermatol. 2013; 133 (5): 1178-87.

14. Goh AM, Coffill CR, Lane DP. The role of mutant p53 in human cancer. J Pathol. 2011; 223: 116-26.

15. Muller PA, Vousden $\mathrm{KH}$, Norman JC. p53 and its mutants in tumor cell migration and invasion. J Cell Biol. 2011; 192: 209-18.

16. Longo PA, Kavran JM, Kim M-S, Leahy DJ. Transient mammalian cell transfection with polyethylenimine (PEI). Methods Enzymol. 2013; 529: 227-40.

17. Riss TL, Moravec RA, Niles AL, Duellman S, et al. Cell viability assays. In Assay Guidance Manual; Sittampalam GS, Grossman A, Brimacombe K, Arkin M, et al, Eds.; Eli Lilly \& Company and the National Center for Advancing Translational Sciences: Bethesda (MD), 2004.

18. McQuin C, Goodman A, Chernyshev V, Kamentsky L, et al. CellProfiler 3.0: Next-generation image processing for biology. PLOS Biol. 2018; 16 (7): e2005970. Available at: https://doi. org/10.1371/journal.pbio.2005970.

19. R Core Team. R: A language and environment for statistical computing: R foundation for statistical computing: Vienna, Austria. 2013.

20. Eckert RL, Yaffe MB, Crish JF, Murthy S, Rorke EA, Welter JF. Involucrin - structure and role in envelope assembly. J Invest Dermatol. 1993; 100 (5): 613-7.

21. Greenberg CS, Birckbichler PJ, Rice RH. Transglutaminases: multifunctional cross-linking enzymes that stabilize tissues. FASEB J. 1991; 5 (15): 3071-7.

22. Denecker G, Ovaere P, Vandenabeele P, Declercq W. Caspase-14 reveals its secrets. J Cell Biol. 2008; 180 (3): 451-8.

23. Dlugosz AA, Yuspa SH. Coordinate changes in gene expression which mark the spinous to granular cell transition in epidermis are regulated by protein kinase C. J Cell Biol. 1993; 120 (1): 217-25.

24. Fuchs E, Weber K. Intermediate filaments: structure, dynamics, function, and disease. Annu Rev Biochem. 1994; 63: 345-82.

25. Mogulevtseva YuA, Mezentsev AV, Bruskin SA. RNA interference targeting interstitial collagenase is a potential therapeutic tool to treat psoriasis. Bulletin of RSMU. 2017; (3): 35-42.

26. Xu J, Reumers J, Couceiro JR, De Smet F, Gallardo R, Rudyak S, et al. Gain of function of mutant p53 by coaggregation with multiple tumor suppressors. Nat Chem Biol. 2011; 7: 285-95.

27. Galli $F$, Rossi $M$, D'Alessandra $Y$, De Simone $M$, Lopardo $T$, Haupt Y, et al. MDM2 and Fbw7 cooperate to induce p63 protein degradation following DNA damage and cell differentiation. J Cell Sci. 2010; 123 (14): 2423-33.

\section{Литература}

1. Westfall MD, Mays DJ, Sniezek JC, Pietenpol JA. The $\triangle N p 63 \alpha$ phosphoprotein binds the P21 and 14-3-3 $\sigma$ promoters in vivo and has transcriptional repressor activity that is reduced by Hay-Wells syndrome-derived mutations. Mol Cell Biol. 2003; 23 (7): 2264-76.

2. Botchkarev VA, Flores ER. P53/P63/P73 in the epidermis in health and disease. Cold Spring Harb Perspect Med. 2014; 4 (8): a015248.

3. Koster MI, Roop DR. Mechanisms regulating epithelial stratification. Annu Rev Cell Dev Biol. 2007; 23 (1): 93-113.

4. Martynova E, Pozzi S, Basile V, Dolfini D, Zambelli F, Imbriano C, et al. Gain-of-function p53 mutants have widespread genomic locations partially overlapping with p63. Oncotarget. 2012 Feb; 3 (2): 132-43

5. Ziegler A, Jonason AS, Leffell DJ, Simon JA, Sharma HW, Kimmelman J, et al. Sunburn and P53 in the onset of skin cancer. Nature. 1994; 372 (6508): 773-6.

6. Dazard JE, Piette J, Basset-Seguin N, Blanchard JM, Gandarillas A. Switch from P53 to MDM2 as differentiating human keratinocytes lose their proliferative potential and increase in cellular size. Oncogene. 2000; 19 (33): 3693-705.

7. Freije A, Molinuevo R, Ceballos L, Cagigas M, Alonso-Lecue P, Rodriguez R, et al. Inactivation of P53 in human keratinocytes leads to squamous differentiation and shedding via replication stress and mitotic slippage. Cell Rep. 2014; 9 (4): 1349-60.

8. Seo E-Y, Piao Y-J, Kim J-S, Suhr K-B, Park J-K, Lee J-H. Identification of calcium-induced genes in $\mathrm{HaCaT}$ keratinocytes by polymerase chain reaction-based subtractive hybridization. Arch Dermatol Res. 2002; 294 (9): 411-18.

9. Petushkova NA, Rusanov AL, Pyatnitskiy MA, Larina OV, et al. Proteomic characterization of HaCaT keratinocytes provides new insights into changes associated with SDS exposure. Biomed Dermatol. 2020; 4 (1): 4.

10. Rusanov AL, Nakhod KV, Nakhod VI, Poverennaya EV, Petushkova NA, Luzgina NG. Changes in the proteome of $\mathrm{HaCaT}$ keratinocytes induced by cytotoxic substance Triton X-100. Bull Exp Biol Med. 2017; 163 (5): 620-2.

11. Smits J, Niehues H, Rikken G, van Vlijmen-Willems I, van de Zande G, Zeeuwen P, et al. Immortalized N/TERT keratinocytes as an alternative cell source in 3D human epidermal models. Sci Rep. 2017; 7 (1): pii: 11838.

12. Lehman TA, Modali R, Boukamp P, Stanek J, Bennett WP, Welsh JA, et al. p53 mutations in human immortalized epithelial cell lines. Carcinogenesis. 1993; 14: 833-9.

13. Jung Y-S, Qian Y, Yan W, Chen X. Pirh2 E3 ubiquitin ligase modulates keratinocyte differentiation through P63. J Invest Dermatol. 2013; 133 (5): 1178-87. 
14. Goh AM, Coffill CR, Lane DP. The role of mutant p53 in human cancer. J Pathol. 2011; 223: 116-26.

15. Muller PA, Vousden KH, Norman JC. p53 and its mutants in tumor cell migration and invasion. J Cell Biol. 2011; 192: 209-18.

16. Longo PA, Kavran JM, Kim M-S, Leahy DJ. Transient mammalian cell transfection with polyethylenimine (PEI). Methods Enzymol. 2013; 529: 227-40.

17. Riss TL, Moravec RA, Niles AL, Duellman S, et al. Cell viability assays. In Assay Guidance Manual; Sittampalam GS, Grossman A, Brimacombe K, Arkin M, et al, Eds.; Eli Lilly \& Company and the National Center for Advancing Translational Sciences: Bethesda (MD), 2004.

18. McQuin C, Goodman A, Chernyshev V, Kamentsky L, et al. CellProfiler 3.0: Next-generation image processing for biology. PLOS Biol. 2018; 16 (7): e2005970. Available at: https://doi. org/10.1371/journal.pbio.2005970.

19. R Core Team. R: A language and environment for statistical computing; R foundation for statistical computing: Vienna, Austria. 2013.

20. Eckert RL, Yaffe MB, Crish JF, Murthy S, Rorke EA, Welter JF. Involucrin - structure and role in envelope assembly. J Invest Dermatol. 1993; 100 (5): 613-7.
21. Greenberg CS, Birckbichler PJ, Rice RH. Transglutaminases: multifunctional cross-linking enzymes that stabilize tissues. FASEB J. 1991; 5 (15): 3071-7.

22. Denecker G, Ovaere P, Vandenabeele P, Declercq W. Caspase-14 reveals its secrets. J Cell Biol. 2008; 180 (3): 451-8.

23. Dlugosz AA, Yuspa SH. Coordinate changes in gene expression which mark the spinous to granular cell transition in epidermis are regulated by protein kinase C. J Cell Biol. 1993; 120 (1): 217-25.

24. Fuchs E, Weber K. Intermediate filaments: structure, dynamics, function, and disease. Annu Rev Biochem. 1994; 63: 345-82.

25. Могулевцева Ю. А., Мезенцев А. В., Брускин С. А. Оценка терапевтического потенциала РНК-интерференции интерстициальной коллагеназы для лечения псориаза. Вестник РГМУ. 2017; (3): 37-45.

26. Xu J, Reumers J, Couceiro JR, De Smet F, Gallardo R, Rudyak S, et al. Gain of function of mutant p53 by coaggregation with multiple tumor suppressors. Nat Chem Biol. 2011; 7: 285-95.

27. Galli F, Rossi M, D'Alessandra $Y$, De Simone M, Lopardo T, Haupt Y, et al. MDM2 and Fbw7 cooperate to induce p63 protein degradation following DNA damage and cell differentiation. J Cell Sci. 2010; 123 (14): 2423-33. 